RAMJ

17,2

102

Received 30 May 2021 Revised 23 June 2021 Accepted 14 July 2021

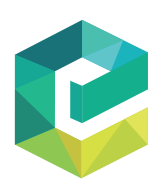

Rajagiri Management Journal Vol. 17 No. 2, 2023 pp. 102-124

Emerald Publishing Limited e-ISSN: 2633-0091

p-ISSN: 0972-9968

DOI 10.1108/RAMJ-05-2021-0045

\section{Measuring dimensions of perceived business success among Malaysian and Bangladeshi SME owners}

\author{
Shehnaz Tehseen \\ Sunway University, Subang Jaya, Malaysia \\ Fatema Johara \\ Bangladesh Army International University of Science and Technology, \\ Comilla, Bangladesh \\ Hussam Al Halbusi \\ Management Department, Ahmed Bin Mohammed Military College (ABMMC), \\ Doha, Qatar \\ Md Asadul Islam \\ Swinburne University of Technology - Sarawak Campus, Kuching, Malaysia, and \\ Fadi Abdel Muniem Abdel Fattah \\ A'Sharqiyah University, Ibra, Oman
}

\begin{abstract}
Purpose - The purpose of this study is to examine the perceptions of Malaysian and Bangladeshi retail smalland medium-sized enterprise (SME) business owners on the key elements of business growth.

Design/methodology/approach - The construct measurements have all been taken from previous research studies. The data were gathered from retail SMEs in Malaysia and Bangladesh in order to evaluate entrepreneurs' perception towards the essential elements of a business performance. Structural equation modeling (SEM) with PLS technique, specifically Smart-PLS Version 3.2.4, was used to accomplish the study's objectives and analyze the measurements, as well as the structural model.

Findings - According to the findings, Malaysian and Bangladeshi SMEs have different perspectives toward the dimensions of their business performance. For example, Malaysian retail SME owners consider business growth and financial results to be the most important aspects of their success. Retailers consider financial performance to be less critical than non-financial performance when it comes to their business's success. Owners of Bangladeshi retail SMEs, on the other hand, see efficiency relative to competition and that nonfinancial performance is the key component to achieving business success. In the sense of Bangladeshi SMEs, market development and financial results are seen as less significant in attaining success.

Research limitations/implications - Since this research was only conducted in Malaysia and Bangladesh, it did not cover a large number of countries. The sample size was limited; therefore, the findings of this study cannot be applied to the entire population of Malaysian and Bangladeshi retail SMEs due to the non-probability sampling technique.

Practical implications - The findings of this study show that entrepreneurs or business owners in the retail sector in Malaysian and Bangladeshi SMEs view the attributes of their business performance differently.

Originality/value - This study adds to the rising context of entrepreneurship by examining SME owners' perception of main business performance dimensions in the scope of Asian retail SMEs.
\end{abstract}

Keywords Business success, Asian retail, SMEs, Malaysia, Bangladesh

Paper type Research paper

(C) Shehnaz Tehseen, Fatema Johara, Hussam Al Halbusi, Md Asadul Islam and Fadi Abdel Muniem Abdel Fattah. Published in Rajagiri Management Journal. Published by Emerald Publishing Limited. This article is published under the Creative Commons Attribution (CC BY 4.0) licence. Anyone may reproduce, distribute, translate and create derivative works of this article (for both commercial and noncommercial purposes), subject to full attribution to the original publication and authors. The full terms of this licence may be seen at http://creativecommons.org/licences/by/4.0/legalcode 


\section{Introduction}

The idea of business success has received a lot of attention in management and entrepreneurship literature because it represents how small- and medium-sized enterprises (SMEs) choose their own success. In particular, it is critical to comprehend business owners' perception toward the critical dimensions of their company's success, as these perceptions can influence their behavior. Numerous past studies have recorded the perspectives of SME owners on the essential metrics and dimensions of market performance (Arzubiaga et al., 2018; Gupta and Mirchandani, 2018; Zakariaa et al., 2016; Gholami et al., 2013; Ahmad et al., 2011; Ahmad et al., 2010; Rai et al., 2006; Hoong et al., 2019). In addition, it is commonly accepted that company owners are a reflection of their business (Ahmad et al., 2018; Chua et al., 2018; Smigielska, 2016; Chuang et al., 2009; Ahmad, 2007; Hambrick, 2007), and the outcome of their companies is determined by their behaviors. This research aims to examine perceived business success measures through the lens of SME entrepreneurs. In this paper, the words "business owners" and "entrepreneurs" are used as interchangeable terms, as the owners of SMEs are true entrepreneurs who put in their best effort to produce superior results.

The SME sector has received a lot of attention in literatures because it is an important factor in any economy's development (Gërguri-Rashiti et al., 2017). Some industries are often more appropriate than others (Rezaei et al., 2013), particularly to gain in-depth understanding of a specific phenomenon (Ahmad, 2007). Therefore, this research looked at the idea of business success through the eyes of retail entrepreneurs in Malaysia and Bangladesh, two developing countries. Entrepreneurship has been emphasized in both countries as a means of advancing economies. It is the practice of pursuing new opportunities in the face of adversity with the purpose of successfully and efficiently combining different variables to achieve superior business performance (Liao et al., 2018; Ramadani et al., 2014). This definition of entrepreneurship is closely related to the term "entrepreneur", which refers to an individual who seeks out new opportunities, takes calculated risks and then combines the best elements to improve quality business success (Honig and Hopp, 2019; Ramadani et al., 2014). As a result, entrepreneurs are regarded as micro-economic agents of economic dynamics (Dana and Mallet, 2014), and understanding the idea of business success through the experience of entrepreneurs is critical. As highlighted by Shanine et al. (2019) and Schauer and Hoy (2001), certain studies have demonstrated scientifically that reported entrepreneurship research studies are not always in line with business owners' viewpoints and interests. Thus, there should be an assessment on reality-vs-general perceptions (Schauer and Hoy, 2001). This is only possible by concentrating on specific contexts in any phenomenon, as it has been widely emphasized that context-specific viewpoints are crucial to understanding entrepreneurship better (Welter and Gartner, 2016). The purpose of this paper is to contribute to the entrepreneurship research literature by providing Asian perspectives (perception of business owners/entrepreneurs from Malaysia and Bangladesh) on business performance measures in specific contexts.

Though entrepreneurs have tried to establish their own companies as SMEs, they fail to manage them on a long-term basis (Johara et al., 2017). The causal consequence is that the failure rate of SMEs in developing countries such as Malaysia and Bangladesh is over $50 \%$ (Nik et al., 2016; Khalique et al., 2011). Therefore, it is critical to comprehend the idea of business success from the eyes of small-business owners. Successful SMEs act as the backbone of a country's economy and contribute toward GDP, employment, exports and productivity. On the other hand, failing SMEs are unable to contribute significantly to the growth of the country's economy, resulting in residual unemployment. Similarly, a number of studies have acknowledged the importance of SMEs toward the country's GDP, social uplifting, employment, exports and productivity (Dutta, 2017; Cravo et al., 2012; Radam et al., 2008; Karides, 2005; Amini, 2004; Tehseen et al., 2020a, b). Therefore, this research recognizes
Dimensions of perceived business success 
RAMJ

17,2

104

the value of good SMEs, and it aims to investigate business owners' views on the essential aspects of business performance. According to Carton and Hofer (2006), the drawbacks of qualitative analysis, which is primarily interpretive, complicate and contrast organizations and companies, despite the fact that a variety of contexts and interpretations play an important role in performance measurement. Given the massive interdependencies among financial and non-financial results, Velte (2017) engendered a significant influence on existing literatures.

Based on an integrative analysis of the literature, the current research argues for the use of both financial and non-financial metrics of performance. A thorough analysis of the literature from different contexts was conducted to avoid dismissing any critical performance criterion widely used in the sense of SMEs, both locally and globally. This research has revealed the disparities in business owners' views on main success factors. The second section of this paper is devoted to a review of the literature. It will explain how SMEs are described in Malaysia and Bangladesh. Then it will present a short literature review on the theory of business performance, followed by a summary of the retail industry in both countries.

\section{Theory and literature review}

\subsection{Definition of SMEs}

SMEs, since the last eras of the twentieth Century, are special styles of businesses that have gained a lot of attention and importance (Rakićević et al., 2016; Zahan, 2017). The "smalland medium-sized enterprise" is the most widely-used word, and although it is still an unclear definition, it conveys the main idea of an SME as a small, but focused, business (Yan, 2015). Researchers have used different approaches to define SMEs. For instance, according to North and Varvakis (2016), SME is defined as "a small social system whose members share a mutual interest in its existence and participate in collective actions to ensure this end". This definition describes SMEs as social entities with the weaknesses and strengths to effectively deal with their turbulent environments. According to North and Varvakis (2016), the broad idea of a small business is based on two key criteria: (1) turnover and (2) employee count. However, this definition varies by country. Given the variety of SMEs, most countries use quantitative definitions to capture the fundamental characteristics of SMEs. The Malaysian and Bangladeshi meanings of SMEs are shown in Tables 1 and 2, correspondingly.

Table 1.

Definition of SMEs in Malaysia (by size of operation)

\begin{tabular}{llll}
\hline Category & Micro & Small & Medium \\
\hline Manufacturing & Sales turnover of less & Sales turnover from & Sales turnover from RM15 \\
& than RM300,000 & RM300,000 to less than & million to not exceeding RM50 \\
& OR & RM15 million & million \\
& Employees of less & OR & OR \\
& than 5 & Full-time employees from 5 & Full-time employees from 75 to \\
& & to less than 75 & not exceeding 200 \\
Service and other & Sales turnover of less & Sales turnover from & Sales turnover from RM3 \\
sectors & than RM300,000 & RM300,000 to less than RM3 & million to not exceeding RM20 \\
& OR & million & million \\
& Employees of less & OR & OR \\
& than 5 & Full-time employees from 5 & Full-time employees from 30 to \\
& & to less than 30 & not exceeding 75
\end{tabular}

Source(s): SME Corp (2015) 


\begin{tabular}{|c|c|c|c|c|}
\hline Category & Micro & Small & Medium & \\
\hline \multirow[t]{2}{*}{ Manufacturing } & $\begin{array}{l}\text { Amount of investment is } 10 \\
\text { lakh to } 75 \text { lakh } \\
\text { (Replacement cost and } \\
\text { value of fixed assets, } \\
\text { excluding land and factory } \\
\text { buildings) } \\
\text { OR }\end{array}$ & $\begin{array}{l}\text { Amount of investment is } 75 \\
\text { lakhs to } 15 \text { crores } \\
\text { (Replacement cost and } \\
\text { value of fixed assets, } \\
\text { excluding land and factory } \\
\text { buildings) } \\
\text { OR }\end{array}$ & $\begin{array}{l}\text { TT amount of investment is } \\
15 \text { crores to } 50 \text { crores } \\
\text { (Replacement cost and } \\
\text { value of fixed assets, } \\
\text { excluding land and factory } \\
\text { buildings) } \\
\text { OR }\end{array}$ & $\begin{array}{l}\text { business } \\
\text { success }\end{array}$ \\
\hline & $\begin{array}{l}\text { Number of employed } \\
\text { Workers are } 16-30\end{array}$ & $\begin{array}{l}\text { Number of employed } \\
\text { workers are } 31-120\end{array}$ & $\begin{array}{l}\text { Number of employed } \\
\text { workers are } 121-300\end{array}$ & \\
\hline \multirow[t]{2}{*}{$\begin{array}{l}\text { Services and } \\
\text { other sectors }\end{array}$} & $\begin{array}{l}\text { Amount of investment is } 10 \\
\text { lakh to } 75 \text { lakh } \\
\text { (Replacement cost and } \\
\text { value of fixed assets, } \\
\text { excluding land and factory } \\
\text { buildings) } \\
\text { OR }\end{array}$ & $\begin{array}{l}\text { Amount of investment is } 10 \\
\text { lakh to } 2 \text { crores } \\
\text { (Replacement cost and } \\
\text { value of fixed assets, } \\
\text { excluding land and factory } \\
\text { buildings) } \\
\text { OR }\end{array}$ & $\begin{array}{l}\text { Amount of investment is } 10 \\
\text { lakh to } 2 \text { crores to } 30 \text { crores } \\
\text { (Replacement cost and } \\
\text { value of fixed assets, } \\
\text { excluding land and factory } \\
\text { buildings) } \\
\text { OR }\end{array}$ & \\
\hline & $\begin{array}{l}\text { Number of employed } \\
\text { workers are } 16-30\end{array}$ & $\begin{array}{l}\text { Number of employed } \\
\text { workers are 16-50 }\end{array}$ & $\begin{array}{l}\text { Number of employed } \\
\text { workers are } 51-120\end{array}$ & $\begin{array}{r}\text { Tal } \\
\mathrm{n} \text { of SN }\end{array}$ \\
\hline \multicolumn{4}{|c|}{ Source(s): Ministry of Industry (2016) } & \\
\hline
\end{tabular}

\subsection{Malaysian and Bangladeshi retail SMEs}

Due to the purchase of products and services by consumers for personal, family or household uses, retailing is critical in commercial transactions. Therefore, retailers are actively involved in the delivery of products and services to customers. The retail industry, which is a significant segment in the service sector, is widely regarded as the most important in the world due to its crucial contributions to economic development, as well as a country's GDP. While Malaysia's manufacturing industry accounts for only $5.9 \%$ of the country's overall business establishments, the Malaysian retail industry has a major share of the country's GDP of more than $14 \%$ in the previous years of 2012, 2013 and 2014 . Similarly, $50 \%$ of the total GDP of Bangladesh's economy is covered by the largest sector that provides services: wholesaling, retailing and trading; transportation, storage and communication; as well as real estate renting and leasing are the most important parts within the service sector. They are business activities that cover $14 \%, 11 \%$ and $7 \%$, respectively, of the total GDP. On the contrary, the industrial sector only accounts for a total $30 \%$ of the GDP. As the wholesale and retail SMEs of both countries represent the largest segment of the service sector and contribute more toward a country's GDP and employment, this demonstrates the importance of wholesale and retail SMEs in both the countries' economies. Numerous studies have recognized the value of good SMEs for a country's economic growth and development (Tehseen and Sajilan, 2016; Tehseen et al., 2015; Sajilan and Tehseen, 2015; Tehseen and Ramayah, 2015; Ahmad et al., 2011). Apart from that, retailers have also been attempting for several years to identify the crucial success factors that may affect their business results (Mekraz and Gundala, 2016). Therefore, to better understand the measures associated with business success in Malaysian SMEs, it is necessary to first understand the meaning of business success, which is why wholesale and retail SMEs have been selected specifically for this research.

\subsection{The concept of business success}

What constitutes as the strongest indicator of performance is still a point of contention. Previous researches have indicated the rigid use of financial metrics, while others have 
RAMJ

17,2

106

emphasized the importance of non-financial success indicators. Based on a past literature, traditional cost-effective measures of performance such as profitability, sales turnover and return on investment take precedence in deciding whether or not a company is profitable (Bruderl and Preisendorfer, 1998). This research team also disagrees that, in order to become effective organizations, they must generate profit, increase profit and demonstrate some degree of development, as stated in their sales and profit reports (Perren, 2000). Hall and Fulshaw (1993) stated that development is associated with long-term success, while profitability is associated with short-term success. Some scholars have claimed that not all small businesses strive to expand, and for some entrepreneurs, success merely means surviving or maintaining the company that they have built (Whitson et al., 2018; Beaver, 2002). This group affirms that, even though growth is not considered important, survival in business also entails a firm to be financially feasible. The belief that "businesses are only successful if they are financially solvent" may have influenced researchers who use this method (Marlow and Strange, 1994, p. 179). The latter party, on the other hand, compelled the value of non-financial indicators of progress (Frese et al., 2002; Hoque, 2004; O'Regan and Ghobadian, 2004). The basis for doing so is made apparent by Jenning and Beaver (1997) who disagreed that, contrary to common opinion and economic theory, the pursuit of individual economic fortune and money is less important than the desire for independent quality of life, direct interest and responsibility that many small business owners and managers strive for. As a result, achieving these goals is one of the most important requirements for success, as described by the entrepreneur/owner-manager.

The above expresses the idea that, for small businesses, the most important metric of success is the achievement of personal goals such as autonomy, personal engagement and work-life balance, rather than financial results. In a parallel stratum, Beaver (2002) illustrated that revenue is not a primary motivator for many entrepreneurs, but rather a "satisfying byproduct" that allows them to take control of their own goals. Entrepreneurship research has focused on a limited definition of success, concentrating solely on company success as measured by "hard" indicators of firm efficiency (Ahmad et al., 2011; Islam et al., 2019). Studies have largely ignored the "softer," more personally established standards of success that represent the internal profession due to their low expectations. Accordingly, Walker and Brown's (2004) financial and non-financial metrics can be used in tandem to provide a more complete picture of real results. Even though focusing solely on financial results may be inadequate, ignoring this metric of success may introduce bias into the calculation of successful business. More recently, Ahmad and Seet (2009) mentioned that financial and nonfinancial criteria have been identified in interviews conducted among 10 SME foundermanagers in the northern region of Peninsular Malaysia. Despite the fact that the research was conducted in an eastern environment, the findings have yet to be empirically validated. As mentioned previously, the shortcomings of primarily interpretive and qualitative analysis make it difficult to compare and contrast organizations and businesses, particularly when there are a variety of contexts, and that context plays an important role in evaluating success (Carton and Hofer, 2006). As a result, an analysis should be conducted to verify and confirm the dimensions of the features of a business performance structure, as it relates to SMEs.

Both eastern and western contexts are covered in the literature. The present research is unique in that it employs both financial and non-financial performance indicators. This is to avoid ignoring critical performance metrics that have often been used in the context of SMEs, both nationally and globally. Profitability, revenue turnover, revenue growth, return on investment and market share are examples of financial metrics (Chandler and Hanks, 1993), whereas customer satisfaction and retention, owner self-satisfaction, firm image and reputation, employee satisfaction and good working relations are among the non-financial indicators (Ahmad and Seet, 2009). In the manufacturing and service industries, customer satisfaction is linked to repurchase intent. If customers are pleased, they are more likely to 
suggest the firm's products or services to other prospective consumers (Haber and Reichel, 2005; Adams and Sykes, 2003). On the other hand, customer retention, which refers to loyalty, is also a critical non-financial performance metric, as it has been shown to increase market share and profitability (Haber and Reichel, 2005). Customer retention and satisfaction are two non-financial outcomes that have been listed in the popular literature (O'Regan and Ghobadian, 2004), as well as the owner's satisfaction with and perception of his or her own professional advancement (Frese et al., 2002). Employee satisfaction, supplier relations, successful corporate image, workplace relations and maintaining work-life balance have also been highlighted by other researchers as significant non-financial metrics of performance (Hoque, 2004; Walker and Brown, 2004).

\section{Method}

\subsection{Survey instrument}

The construct measurements were all taken from previous studies; therefore, the reliability of these measures has also been recorded. According to the studies of Hoque (2004) and Stephan (2018), non-financial performance is measured using employee satisfaction, customer satisfaction, workplace industrial relations and supplier relationships. For instance, Chandler and Hanks (1993) identified a Cronbach's alpha value of 0.77 internal consistency for their measure. In this study, satisfaction with financial success, including sales growth, profitability, sales turnover and return on investment, was estimated. In another research, Hoque (2004) noted a high internal consistency with a Cronbach's alpha value of 0.75 . Five items have been introduced to this measure to define success: (1) customer retention, (2) business image, (3) overall satisfaction, (4) career progress and (5) balance between work and family life (Ahmad and Seet, 2009). Besides that, Chandler and Hanks (1993) stated that a selfreport of performance on "objective" financial indicators includes estimates of the firm's performance relative to its competitors. This six-item scale, which consists of market share, return on sales, sales growth, cash flow, net profit and return on investment, has reported a moderate internal reliability value of 0.53 . Based on previous studies, business growth was measured by examining changes in sales, market share and cash flow growth. The scale reported a good Cronbach's alpha value of 0.72 (Chandler and Hanks, 1993). According to Haber and Reichel (2005), similar measures in their study also reported a high internal consistency of 0.92 .

\subsection{Sample and data}

We studied retail SMEs in Malaysia and Bangladesh to identify how they felt about the important aspects of business performance. The data have been obtained from 80 Malaysian retail SMEs and 80 Bangladeshi retail SMEs in Malaysia and Bangladesh, respectively. Their demographic profiles are shown in Table 3. Non-probability sampling technique was adopted to collect the data, with purposive sampling used for the survey. The material validity of the interventions was then investigated, as indicated by Dana and Dana (2005) to avoid type III errors that might be caused by the wrong question asked during survey. To obtain full answers, a face-to-face interview was conducted with the respondents. Using four dimensions to analyze the current structure, a minimum sample size of 95 creates a power of 0.80 for the research model, with a medium effect size (Hair et al. 2014, 2017). Therefore, a total of 160 data from both countries have been analyzed for the purpose of the study that would result in a new product with the power of 0.98 for the research model with a medium effect size of 0.15 . Table 1 provides the sample data's demographic details. The items were adopted for all aspects of business performance from Ahmad (2007), and the research model for this present study is shown in Figure 1.

\section{Dimensions of perceived business \\ success




\begin{tabular}{|c|c|c|c|c|c|c|c|}
\hline \multirow{2}{*}{$\begin{array}{l}\text { RAMJ } \\
17,2\end{array}$} & \multirow{2}{*}{ Characteristics } & \multicolumn{2}{|c|}{ Full sample $(N=160)$} & \multicolumn{2}{|c|}{$\begin{array}{c}\text { Malaysian retail SMEs } \\
\quad(N=80)\end{array}$} & \multicolumn{2}{|c|}{$\begin{array}{c}\text { Bangladeshi retail SMEs } \\
\quad(N=80)\end{array}$} \\
\hline & & Frequency & Percentage & Frequency & Percentage & Frequency & Percentage \\
\hline \multirow{4}{*}{108} & $\begin{array}{l}\text { Gender } \\
\text { Male } \\
\text { Female }\end{array}$ & $\begin{array}{r}109 \\
51\end{array}$ & $\begin{array}{l}68.12 \\
31.87\end{array}$ & $\begin{array}{l}34 \\
46\end{array}$ & $\begin{array}{l}42.5 \\
57.5\end{array}$ & $\begin{array}{r}75 \\
5\end{array}$ & $\begin{array}{r}93.75 \\
6.25\end{array}$ \\
\hline & $\begin{array}{l}\text { Age } \\
31-40 \\
41-50 \\
51-60\end{array}$ & $\begin{array}{l}32 \\
83 \\
45\end{array}$ & $\begin{array}{l}20.00 \\
51.87 \\
56.25\end{array}$ & $\begin{array}{l}22 \\
38 \\
20\end{array}$ & $\begin{array}{l}27.5 \\
47.5 \\
25.0\end{array}$ & $\begin{array}{l}10 \\
45 \\
25\end{array}$ & $\begin{array}{l}12.50 \\
56.25 \\
31.25\end{array}$ \\
\hline & $\begin{array}{l}\text { Marital status } \\
\text { Single } \\
\text { Married } \\
\text { Divorced } \\
\text { Widowed }\end{array}$ & $\begin{array}{r}34 \\
88 \\
35 \\
3\end{array}$ & $\begin{array}{r}21.25 \\
55.00 \\
21.87 \\
1.87\end{array}$ & $\begin{array}{r}17 \\
43 \\
17 \\
3\end{array}$ & $\begin{array}{r}21.3 \\
53.8 \\
21.3 \\
3.8\end{array}$ & $\begin{array}{r}17 \\
45 \\
18 \\
0\end{array}$ & $\begin{array}{c}21.25 \\
56.25 \\
22.50 \\
0\end{array}$ \\
\hline & $\begin{array}{l}\text { Highest education } \\
\text { Diploma } \\
\text { Bachelor's Degree } \\
\text { Master's Degree } \\
\mathrm{PhD}\end{array}$ & $\begin{array}{r}33 \\
77 \\
45 \\
5\end{array}$ & $\begin{array}{c}20.62 \\
48.12 \\
28.12 \\
3.125\end{array}$ & $\begin{array}{r}23 \\
37 \\
15 \\
5\end{array}$ & $\begin{array}{r}28.8 \\
46.3 \\
18.8 \\
6.3\end{array}$ & $\begin{array}{r}10 \\
40 \\
30 \\
0\end{array}$ & $\begin{array}{c}12.5 \\
50.0 \\
37.5 \\
0\end{array}$ \\
\hline $\begin{array}{l}\text { Table } 3 . \\
\text { Demographic profile of } \\
\text { respondents }\end{array}$ & $\begin{array}{l}\text { Firm age } \\
3-5 \text { years old } \\
6-10 \text { years old } \\
11-20 \text { years old }\end{array}$ & $\begin{array}{l}14 \\
73 \\
73\end{array}$ & $\begin{array}{r}8.75 \\
45.62 \\
45.62\end{array}$ & $\begin{array}{r}9 \\
43 \\
28\end{array}$ & $\begin{array}{l}11.3 \\
53.8 \\
35.0\end{array}$ & $\begin{array}{r}5 \\
30 \\
45\end{array}$ & $\begin{array}{r}6.30 \\
37.50 \\
56.25\end{array}$ \\
\hline
\end{tabular}

\subsection{Demographic data analysis}

The demographic profile reveals that there are $42.5 \%$ males and $57.5 \%$ females in the Malaysian sample, and $93.75 \%$ males and $6.25 \%$ females in the Bangladeshi sample. The majority of the respondents belong to the age group of 41-50 years old in both samples. $48 \%$ of the total respondents have a Bachelor's degree. $67.50 \%$ SMEs have small businesses $(60 \%$ from the Malaysian sample and $75.50 \%$ from the Bangladeshi sample), while $32.50 \%$ SMEs own medium-sized businesses $(32.50 \%$ from the Malaysian sample and $25.0 \%$ from the Bangladeshi sample). The other demographic details are shown in Table 3.

\section{Findings}

\subsection{Inferential data analysis}

Obtaining the study's goals and analyzing the data involves using a measurement model and structural model; structural equation modeling (SEM) with PLS technique, particularly the Smart-PLS Version 3.2.4, was applied. The PLS-SEM is similar to the analysis of multiple regression, which investigates relationships by focusing less on the measurement model (Hair et al., 2017). PLS-SEM technique was used in this study because it involves a secondorder construct (i.e. business success) and works well with a small sample size (Hair et al., 2017; Tehseen et al., 2020a, b; Tehseen et al., 2019; Islam et al., 2020; Hossain et al., 2021). Furthermore, this technique has been applied in many studies to examine the relationship between constructs (Henseler et al., 2015; Bahar et al., 2020; Hossain et al., 2021). In the PLS structure model, individual path coefficients can be interpreted as the standardized beta coefficients of OLS regression (Götz et al., 2010). The significance of each path coefficient can be accessed through the procedure of bootstrapping, whereby the significant paths 


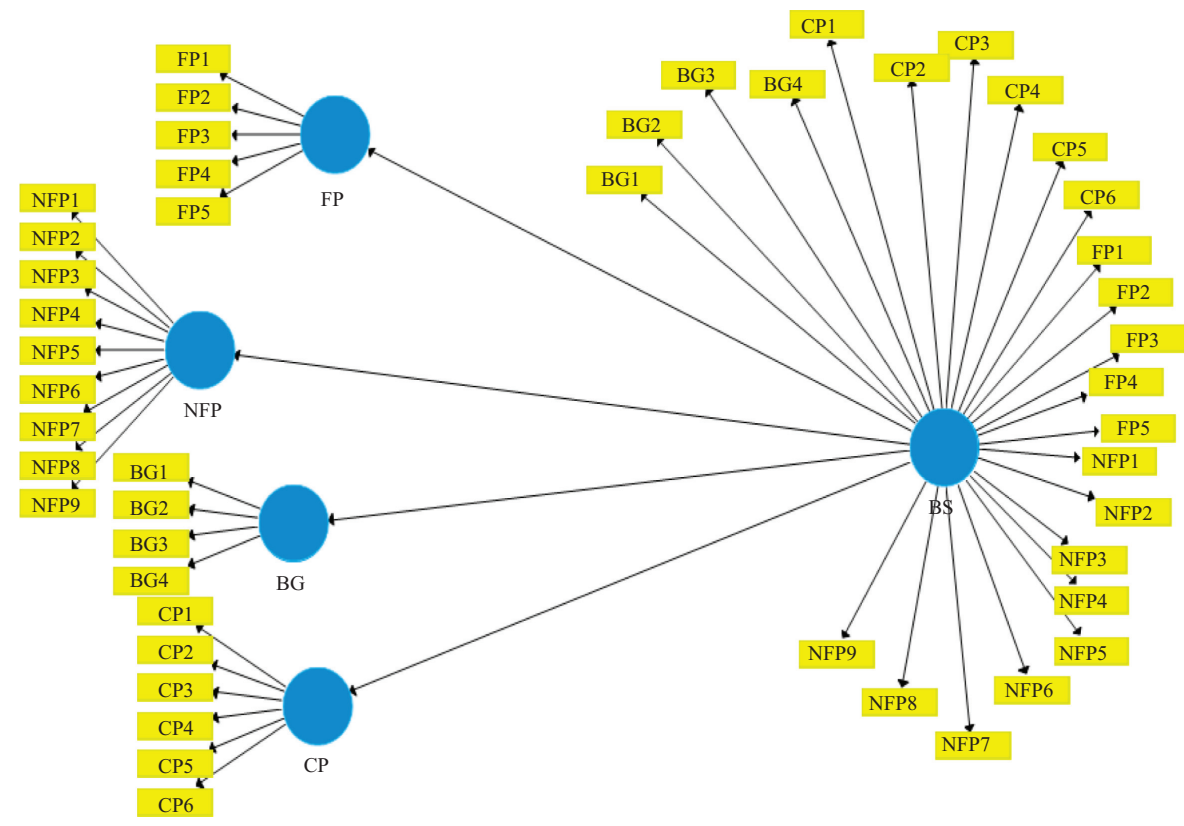

Note(s): FP indicates financial performance; NFP represents non-financial performance; BG indicates business growth; and $\mathrm{CP}$ represents performance relative to competitors
Dimensions of perceived business

success

109

representing the hypothesized direction provide empirical support for the proposed path relationship and vice versa (Hair et al., 2011; Yung and Bentler, 1994). The process of bootstrapping is a nonparametric test in PLS, which includes repeated random sampling with the replacement from the original sample in order to develop a bootstrap sample and achieve the standard errors to test the relationships (Hair et al., 2011). The current study used bootstrapping with 1,000 re-samples to test the significance of the regression or path coefficients according to the suggestions of Chin (2010). The path coefficients have standardized values of between -1 and +1 . The path coefficients closer to +1 indicate a strong positive relationship, while those closer to -1 represent a strong negative relationship (Hair et al., 2017). Moreover, PLS is more suitable in carrying out a multi-group analysis on the SMEs across two different countries and can also explore the differences. The respondents of Malaysian retail SMEs and Bangladeshi SMEs were split into two different data sets $(80$ samples in each group). In order to estimate the results of the structure model, all criteria such as discriminant validity, convergent validity and measurement invariance were examined separately according to the suggestions of Hair et al. (2017). According to Hair et al. (2009), the items' factor loadings, the constructs' average variance extracted (AVE) and CR are used to examine the data's convergence validity. Therefore, to ensure the reliability of the indicators, the main loadings and cross-loading of items were also checked. We also followed the suggestions of Chin (1998) and retained the items whose factor loadings exceeded the recommended value of 0.6. With reference to Hair et al. (2017) and Hair et al. (2014), we retained or deleted the items with poor factor loadings after examining the impact of their removal, both on the values of convergent validity and composite reliability (CR). For example, if the deletion of an item with a low factor loading could not improve the value of $\mathrm{AVE}$ and $\mathrm{CR}$, it is then retained in the model; otherwise, it is deleted. Hence, the items FP4, 
RAMJ

17,2

110

NFP2, NFP3, NFP4, NFP6, NFP8, CP2 and CP4 with factor loadings below 0.4 were removed in order to improve the values of $\mathrm{AVE}$ and $\mathrm{CR}$. The AVE of all the other constructs was more than the cutoff value of 0.5, as suggested by the literatures (Hair et al., 2014; Henseler et al., 2009). Apart from that, the values for the composite reliability of the constructs were above the minimum threshold value of 0.7, as proposed by Hair et al. (2011). Tables 4 and 5 show the results of the measurement model analysis.

After analyzing the convergent validity of the model, an analysis of its discriminant validity was also undertaken. Two approaches were used to examine the discriminant validity of the model. The first approach is the Fornell and Larcker criterion, in which the discriminant validity is examined for both the full and split samples by comparing the correlation among the constructs and the square root of AVE for that construct (Fornell and Larcker, 1981). The results revealed that the square roots of AVEs for all the constructs are greater than the off-diagonal elements in both their corresponding rows and columns, which suggest that the discriminant validity is established for the full and sub-models (Table 6).

Henseler et al. (2015) suggested the assessment of the correlations' heterotrait-monotrait ratio (HTMT) to examine the discriminant validity. This recent approach indicates the estimation of the true correlation between two latent variables. A threshold value of 0.90 for HTMT, as well as a confidence interval of HTMT of less than 1 have been suggested as the threshold value for assessing discriminant validity through HTMT (Henseler et al., 2015). Table 7 shows that the HTMT criterion has been fulfilled for our PLS model.

Therefore, in total, the measurement model has shown adequate convergent validity, as well as discriminant validity. After testing the measuring model, the structural model was then analyzed. The values of the path coefficients along with their significance indicate how well the hypothesized model is supported by the data (Chin, 1998). Hence, bootstrapping procedure with a resampling of 1,000 was used to estimate the path coefficient's significance (Chin, 1998). Table 8 shows the path coefficients and their significance for the full and split data.

In addition, as this study involves the comparison of perceptions across two countries, it is thus essential to test the measurement invariance. Hair et al. (2017) stressed that researchers

\begin{tabular}{llccc}
\hline Samples & Constructs & $\begin{array}{c}\text { Cronbach's } \\
\text { alpha }\end{array}$ & $\begin{array}{c}\text { a Composite } \\
\text { reliability }\end{array}$ & $\begin{array}{c}\text { bverage variance extracted } \\
\text { (AVE) }\end{array}$ \\
\hline Full sample & BG & 0.771 & 0.853 & 0.592 \\
& BS & 0.893 & 0.910 & 0.409 \\
& CP & 0.855 & 0.902 & 0.697 \\
Malaysian sample & FP & 0.700 & 0.817 & 0.541 \\
& BFP & 0.720 & 0.843 & 0.641 \\
& BS & 0.697 & 0.811 & 0.519 \\
Bangladeshi & CP & 0.808 & 0.848 & 0.282 \\
sample & FP & 0.730 & 0.829 & 0.552 \\
& NFP & 0.707 & 0.819 & 0.532 \\
& BG & 0.535 & 0.759 & 0.514 \\
& BS & 0.759 & 0.848 & 0.583 \\
& CP & 0.898 & 0.915 & 0.431 \\
& FP & 0.889 & 0.924 & 0.753 \\
& NFP & 0.631 & 0.789 & 0.530 \\
& 0.763 & 0.863 & 0.678
\end{tabular}

Table 4.

Constructs' validity and reliability

Note(s): ${ }^{\mathrm{C} C o m p o s i t e}$ reliability $(\mathrm{CR})=$ (square of the sum of factor loadings)/ $\{$ (square of the sum of factor loadings) + (square of the sum of error variances) $\} ;{ }^{\mathrm{b}}$ Average variance extracted (AVE) $=($ sum of the square of factor loadings)/\{(sum of the square of factor loadings) + (sum of the error variances)\}

Source(s): Own survey results 


\begin{tabular}{|c|c|c|c|c|c|}
\hline Constructs & Items & $\begin{array}{l}\text { Full sample }(N=160) \\
\text { Factor loading }\end{array}$ & $\begin{array}{l}\text { Malaysian sample }(N=80) \\
\text { Factor loading }\end{array}$ & $\begin{array}{c}\text { Bangladeshi sample }(N=80) \\
\text { Factor loading }\end{array}$ & $\begin{array}{r}\text { Dimensions of } \\
\text { perceived }\end{array}$ \\
\hline \multirow[t]{4}{*}{ BG } & BG1 & 0.752 & 0.770 & 0.668 & USImess \\
\hline & BG2 & 0.753 & 0.608 & 0.775 & success \\
\hline & BG3 & 0.800 & 0.779 & 0.822 & \\
\hline & BG4 & 0.752 & 0.712 & 0.782 & \\
\hline \multirow[t]{4}{*}{$\mathrm{CP}$} & $\mathrm{CP} 1$ & 0.804 & 0.755 & 0.798 & 111 \\
\hline & CP3 & 0.861 & 0.865 & 0.859 & \\
\hline & CP5 & 0.839 & 0.726 & 0.899 & \\
\hline & CP6 & 0.833 & 0.601 & 0.910 & \\
\hline \multirow[t]{4}{*}{$\mathrm{FP}$} & FP1 & 0.804 & 0.762 & 0.784 & \\
\hline & FP2 & 0.802 & 0.638 & 0.847 & \\
\hline & FP3 & 0.805 & 0.724 & 0.875 & \\
\hline & FP5 & 0.421 & 0.786 & 0.747 & \\
\hline \multirow[t]{3}{*}{ NFP } & NFP1 & 0.823 & 0.744 & 0.837 & \\
\hline & NFP5 & 0.779 & 0.669 & 0.796 & \\
\hline & NFP9 & 0.796 & 0.703 & 0.837 & Table 5 \\
\hline \multicolumn{5}{|c|}{ Source(s): Own survey results } & Factors loadings \\
\hline
\end{tabular}

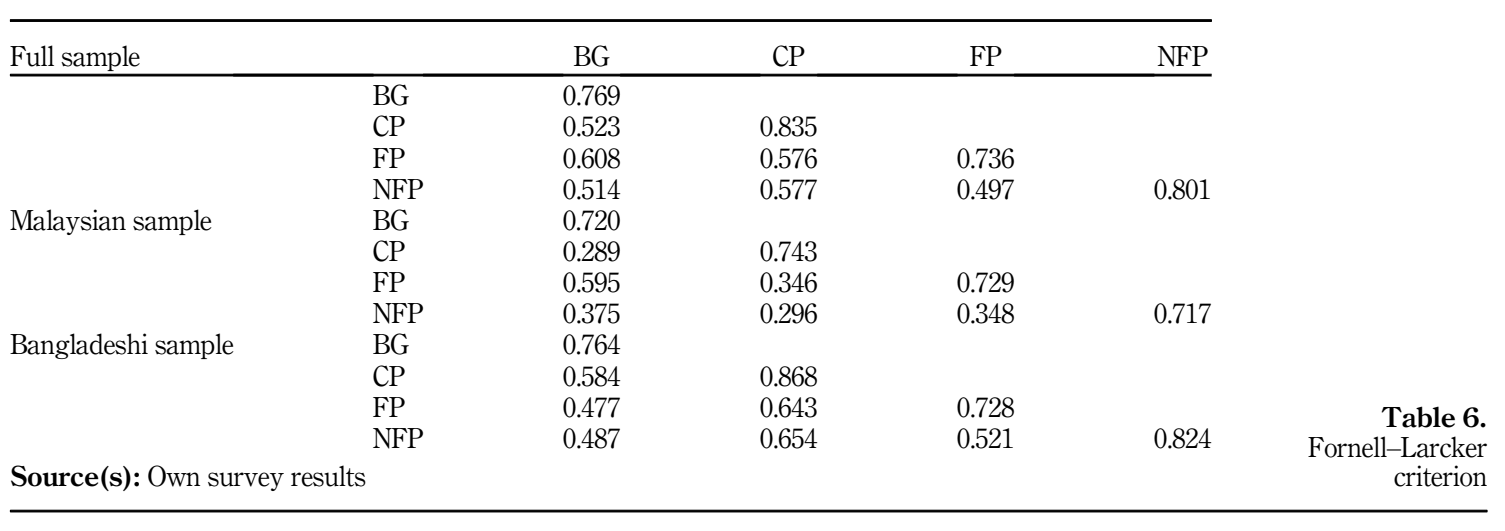

\begin{tabular}{llcccc}
\hline Full sample & & BG & CP & FP & NFP \\
\hline & BG & & & & \\
CP & $0.627(0.499,0.748$ & & & \\
Malaysian sample & FP & $0.806(0.683,0.925)$ & $0.720(0.595,0.852)$ & & \\
& BG & $0.690(0.554,0.821)$ & $0.735(0.599,0.853)$ & $0.679(0.540,0.581)$ & \\
& CP & $0.350(0.279,0.605)$ & & & \\
BPangladeshi sample & NFP & $0.770(0.595,0.974)$ & $0.435(0.284,0.716)$ & & $0.519(0.361,0.919)$ \\
& BG & & & \\
& CP & $0.714(0.508,0.923)$ & $0.446(0.259,0.825)$ & & Table 7. \\
& FP & $0.741(0.509,0.880)$ & $0.830(0.593,0.958)$ & & HTMT criterion \\
\hline
\end{tabular}




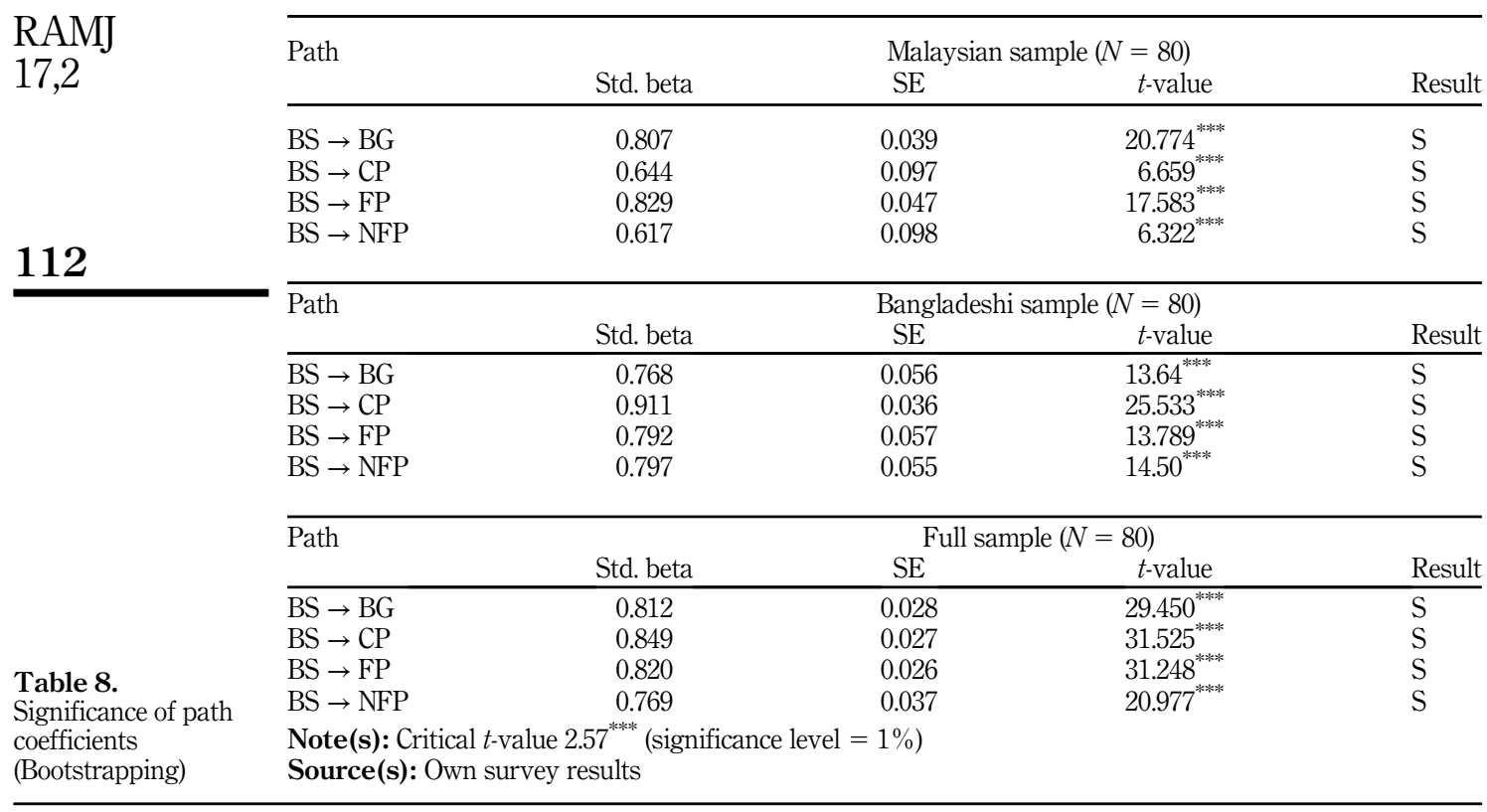

should ensure that the measures of all constructs are invariant across the two groups while comparing their path coefficients by using the PLS-MGA approach. Bootstrapping was used separately for each group and according to the number of observations in the data set.

Levene's test was later applied (Hair et al., 2014, 2017, 2017) to test the measurement invariance for all items through the outer loadings and standard errors for each group. The criterion is that there should not be difference in the measurement items of at least two items of each construct. The results revealed that there is no significant difference between the two groups. Table 9 depicts the results. Levene's test has been used only in a few studies to assess the measurement invariance. For example, a study by Rahman et al. (2015) used this technique to test the measurement invariance for all items while studying service innovation's management practices in telecommunications industry contextually.

As the results have revealed no significant difference between the two groups in the measurement items of at least two items of each construct-application of the multi-group analysis technique, PLS-MGA was used to assess the difference among the path coefficients of both groups. Table 10 shows that significant difference is found in the perception of business owners toward only two dimensions of business success, including performance relative to competitors, as well as non-financial performance between the Malaysian and Bangladeshi samples. This shows that the key dimensions are perceived differently across the two countries. Thus, the dimensions of business success are context-specific and vary across different countries.

\subsection{Common method bias tests}

Contemporarily, the issue of common method variance (CMV) has been addressed within organizational studies that used the same type of respondents for obtaining data (Yuksel, 2017; Tehseen et al., 2017; Jakobsen and Jensen, 2015). Doty and Glick (1998) stated that CMV occurs because of the systematic variance in the measures due to the measurement technique. Richardson et al. (2009) referred to CMV as the systematic error variance shared among 


\begin{tabular}{|c|c|c|c|c|}
\hline & Welch- & atterthwaite test (Invariance & est) & Dimensions of \\
\hline & $\begin{array}{c}\text { Outer loadings-diff (Malaysian- } \\
\text { Bangladeshi) }\end{array}$ & $\begin{array}{l}t \text {-value (Malaysian vs } \\
\text { Bangladeshi) }\end{array}$ & $\begin{array}{l}p \text {-value (Malaysian vs } \\
\text { Bangladeshi) }\end{array}$ & $\begin{array}{r}\text { perceived } \\
\text { business }\end{array}$ \\
\hline $\mathrm{BG} 1 \leftarrow \mathrm{BG}$ & 0.103 & 1.012 & 0.315 & success \\
\hline $\mathrm{BG} 2 \leftarrow \mathrm{BG}$ & 0.167 & $1.815^{*}$ & 0.073 & \\
\hline $\mathrm{BG} 3 \leftarrow \mathrm{BG}$ & 0.043 & 0.680 & 0.499 & \\
\hline $\mathrm{BG} 4 \leftarrow \mathrm{BG}$ & 0.070 & 0.919 & 0.361 & 113 \\
\hline $\mathrm{CP} 1 \leftarrow \mathrm{CP}$ & 0.043 & 0.485 & 0.629 & \\
\hline $\mathrm{CP} 3 \leftarrow \mathrm{CP}$ & 0.006 & 0.101 & 0.920 & \\
\hline $\mathrm{CP} 5 \leftarrow \mathrm{CP}$ & 0.172 & $2.020^{* *}$ & 0.047 & \\
\hline $\mathrm{CP} 6 \leftarrow \mathrm{CP}$ & 0.309 & $2.766^{* * *}$ & 0.007 & \\
\hline $\mathrm{FP} 1 \leftarrow \mathrm{FP}$ & 0.022 & 0.192 & 0.848 & \\
\hline $\mathrm{FP} 2 \leftarrow \mathrm{FP}$ & 0.210 & $1.928^{*}$ & 0.058 & \\
\hline $\mathrm{FP} 3 \leftarrow \mathrm{FP}$ & 0.152 & 1.488 & 0.141 & \\
\hline $\mathrm{FP} 5 \leftarrow \mathrm{FP}$ & 0.638 & $4.261^{* * * *}$ & 0.000 & \\
\hline $\mathrm{NFP} 1 \leftarrow \mathrm{NFP}$ & 0.063 & 0.58 & 0.564 & \\
\hline NFP5 $\leftarrow$ NFP & 0.127 & 0.785 & 0.435 & \\
\hline $\mathrm{NFP} 9 \leftarrow \mathrm{NFP}$ & 0.134 & 1.079 & 0.284 & \\
\hline $\begin{array}{l}\text { Note(s): Criti } \\
\text { (significance le } \\
\text { Source(s): Ov }\end{array}$ & $\begin{array}{l}\text { al } t \text {-values } 1.65^{*} \text { (significance les } \\
\text { el }=1 \% \text { ) } \\
\text { n survey results }\end{array}$ & $1=10 \%), 1.96^{* *}$ (significan & ce level $=5 \%$, and $2.57^{* * * *}$ & $\begin{array}{r}\text { Table } 9 . \\
\text { Invariance test }\end{array}$ \\
\hline Relationships & $\begin{array}{l}\text { Path coefficients-diff } \\
\text { (|Malaysian sample - } \\
\text { Bangladeshi sample|) }\end{array}$ & $\begin{array}{l}t \text {-value (Malaysian sample } \\
\text { vs Bangladeshi Sample) }\end{array}$ & $\begin{array}{l}p \text {-value (Malaysian sample } \\
\text { vs Bangladeshi Sample) }\end{array}$ & \\
\hline $\mathrm{BS} \rightarrow \mathrm{BG}$ & 0.039 & 0.552 & 0.583 & \\
\hline $\mathrm{BS} \rightarrow \mathrm{CP}$ & 0.267 & $2.612^{* * * *}$ & 0.011 & Table 10. \\
\hline $\mathrm{BS} \rightarrow \mathrm{FP}$ & 0.036 & 0.526 & 0.600 & Frndings or mul \\
\hline $\mathrm{BS} \rightarrow \mathrm{NFP}$ & 0.179 & $1.698^{*}$ & 0.093 & $\begin{array}{l}\text { group compariso } \\
\text { between Malaysian }\end{array}$ \\
\hline $\begin{array}{l}\text { Note(s): Critic } \\
\text { Source(s): Ov }\end{array}$ & $\begin{array}{l}\text { t } t \text {-values } 1.65^{*} \text { (significance level } \\
\text { n survey results }\end{array}$ & $=10 \%$ ) and $2.57^{* * * *}$ (significa & nce level = 1\%) & $\begin{array}{r}\text { and Bangladeshi } \\
\text { samples }\end{array}$ \\
\hline
\end{tabular}

variables that are measured with the same method or source. This systematic error variance may cause common method bias and may create biasness in the estimated relationships between the variables or measures (Jakobsen and Jensen, 2015; Campbell and Fiske, 1959). Since this study used the same type of respondents (business owners), as well as the same type of Likert scale to obtain data from both countries, we thus addressed the issue of CMV by using the four statistical remedies to detect and control its impacts. The two techniques, namely partialling out a marker variable, a Lindell and Whitney (2001) method, and correlation matrix procedure, were used to detect the CMV issue in this study. On the other hand, the other two statistical tests, construct-level correction (CLC) approach and item-level correction (ILC) approach, were used to remove any impact of CMV from the findings of this study. These tests are explained below:

4.2.1 Partialling out a marker variable. This is a method introduced by Lindell and Whitney (2001) used to identify CMV issues from any PLS studies. Using this method in the current study, a marker variable was partialled out in our full PLS model to detect the CMV by assessing the correlation between the marker variable and constructs, as shown in Figure 2. CMV was not found as an issue in this study because the correlation between the constructs and marker is not greater than $0.3(r>0.3)$, as shown in Table 11 . 
RAMJ

17,2

114

Figure 2.

Partialling out a

marker variable

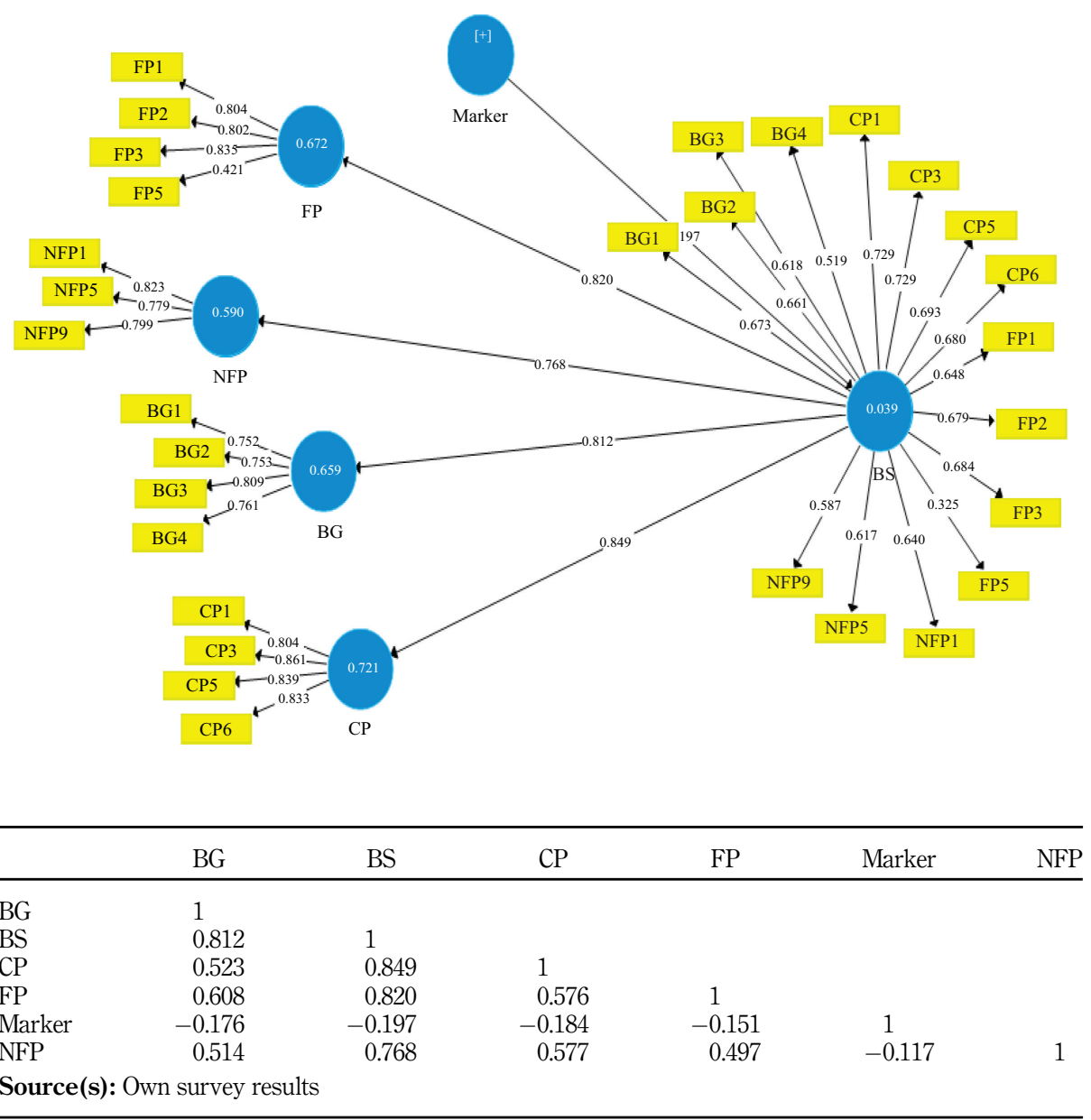

Table 11.

Correlation among

constructs and marker

variable

4.2.2 Correlation matrix procedure. Bagozzi et al. (1991) described the method of identifying the influence of CMV through the constructs' correlations. Thus, following this method, CMV is not evident because a substantially large correlation was not found among the principal constructs $(r>0.9)$, as shown in Table 12 .

\begin{tabular}{llllll}
\hline & BG & BS & CP & FP & NFP \\
\hline BG & 1 & & & & \\
BS & 0.812 & 1 & & & \\
CP & 0.523 & 0.849 & 1 & 1 & \\
FP & 0.608 & 0.820 & 0.576 & 0.497 & 1 \\
NFP & 0.514 & 0.769 & 0.577 & & \\
Source(s): Own survey results & & & &
\end{tabular}

Table 12.

Correlation matrix procedure

Source(s): Own survey results 
4.2.2.1 Measured latent marker variable approach (MLMV). Chin et al. (2013) strongly suggested two approaches to detect and reduce the impact of CMV. The first approach is called the CLC, in which the same number of CMV controls the latent variables as the model's latent variables are created. However, in this study, each CMV control variable used the same set of MLMV items (social desirability items), and the CMV control constructs were modeled as influencing each latent variable of the model, as shown in Figure 3.

The second approach recommended by Chin et al. (2013) is the ILC that involves partialling out MLMV items in order to partial out the influence of CMV at the level of every measurement item of the latent variable. Using this approach in the current study, every measurement item is regressed on all sets of the MLMV items, as shown in Figure 4.

The resulting residuals for every item represent the latent variable's items with the removed influence of CMV. The $R^{2}$ that was used was obtained from every item of the MLMV regression. The square root of the $R^{2}$ was then multiplied with the random error of every measured item and added to each item's residuals. These final ILC items were then used in a PLS analysis of the models, as shown in Figure 5.

Table 13 shows the PLS estimations, as well as the CLC and ILC estimations for the full sample, Malaysian sample and Bangladeshi sample models. The comparative results revealed no significant differences among the PLS estimations, as well as CLC and ILC estimations. Thus, MLMV techniques have provided evidence regarding the reliable results of this study because no significant difference was found between the PLS and MLMV estimates using the CLC and ILC approaches. These statistical tests have proven that even after controlling the impact of CMV through CLC and ILC approaches, the PLS estimations have not changed much in any of the sample models. Thus, CMV is not a serious issue in this study. Past studies have widely used the most common techniques of assessing common method bias such as partialling out a marker variable (Tehseen et al., 2017; Williams et al., 2010; Richardson et al., 2009; Lindell and Whitney, 2001) and the correlation matrix procedure (Kashif et al., 2016; Podsakoff et al., 2003; Bagozzi et al., 1991). However, researchers have also strongly recommended using CLC and ILC techniques to control the impact of CMV, both on the construct level and item level (Tennant, 2014; Chin et al., 2013).

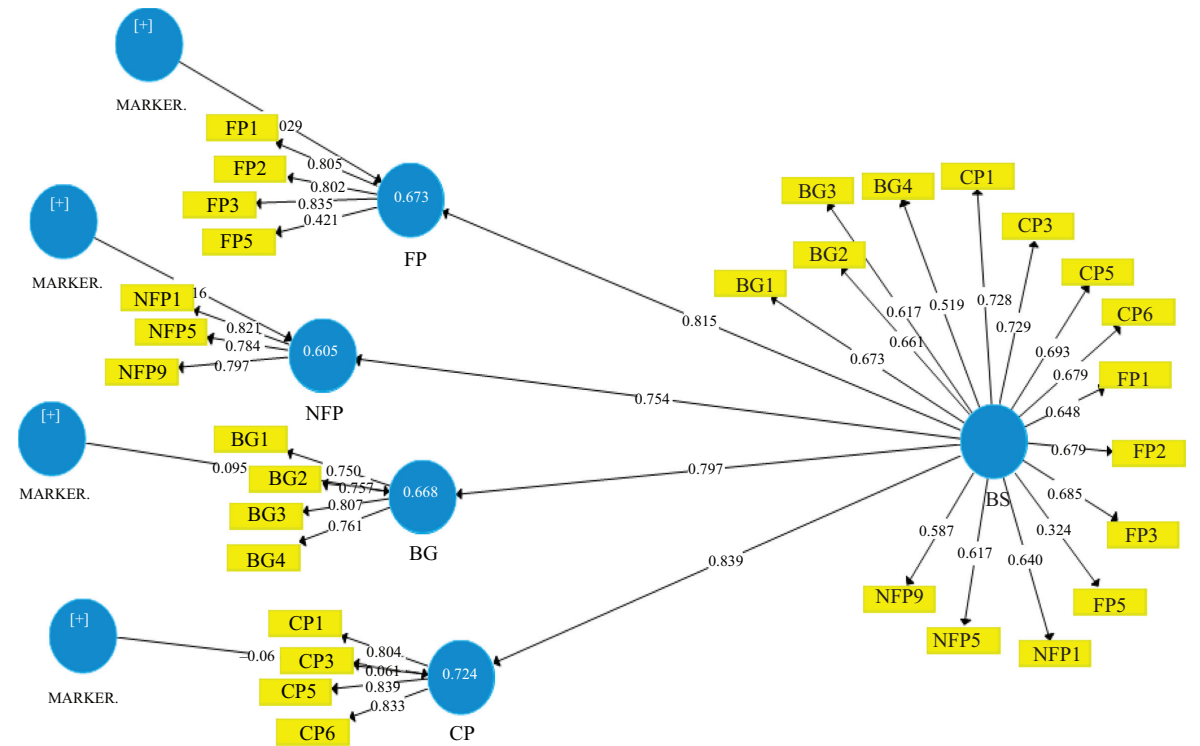

Dimensions of perceived business

success
Figure 3.

Construct-level correction (CLC) approach 
RAMJ

17,2

\section{6}

Figure 4.

Item-level correction (ILC) approach

Figure 5.

ILC model (PLS algorithm)
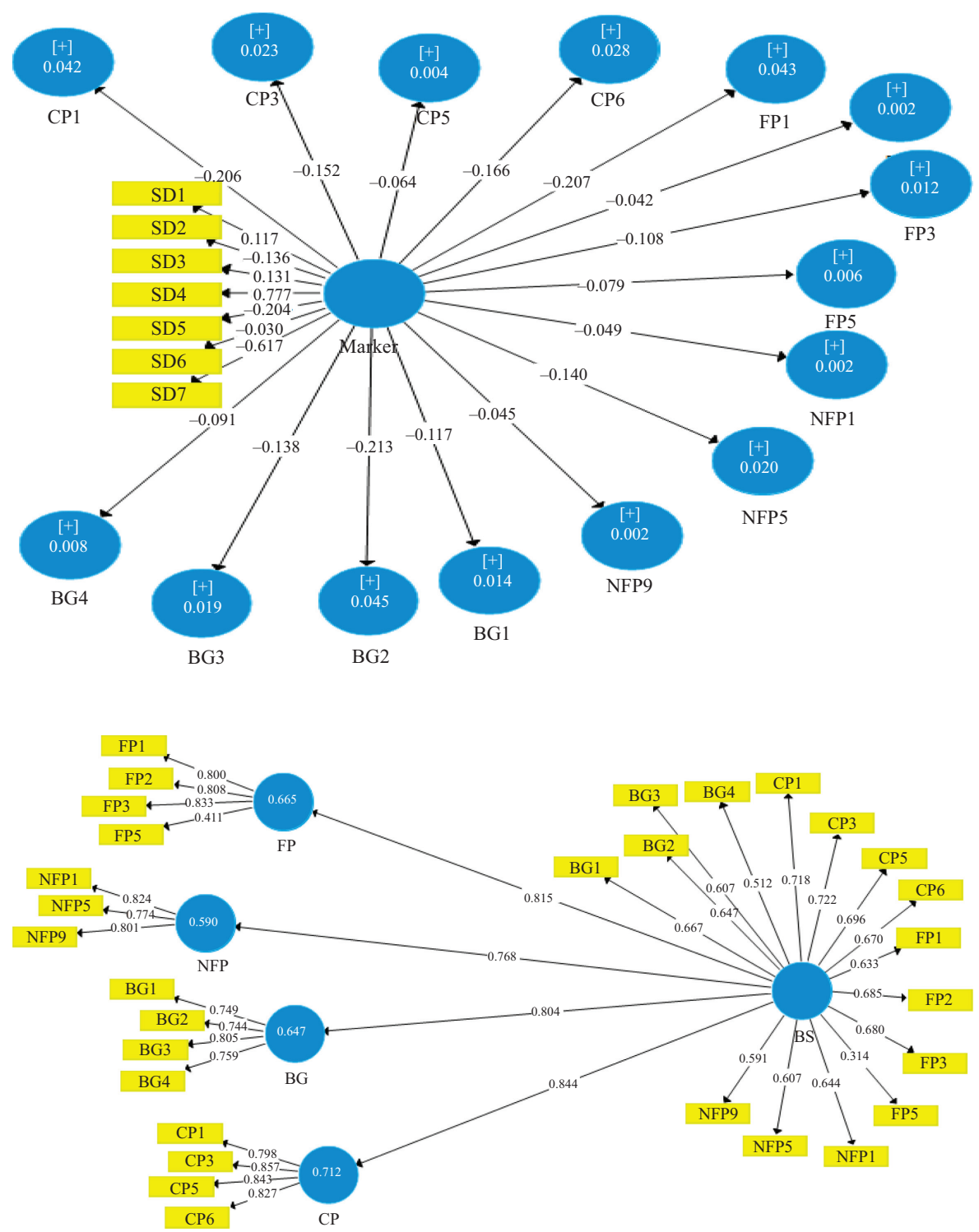

\section{Discussion and implications}

The purpose of this study is to explore the perspective of Malaysian and Bangladeshi retail SME owners on key business success factors. The four major components of business performance have been established previously by Ahmad (2007): (1) financial performance, (2) non-financial performance, (3) market development and (4) performance relative to competitors. Prior studies have also emphasized the role of all four dimensions in achieving business success (Ahmad, 2007). Nevertheless, in various countries, the perception of business owners toward the essential dimensions of business success can differ. Therefore, 
this research has presented empirical data on the views of Malaysian and Bangladeshi retail SME owners. The results suggest that entrepreneurs in these countries have different perspectives on business performance and place a higher value on particular aspects of it. For example, Malaysian retail SME owners place greater emphasis on their companies' growth and financial results in order to achieve success.

On the contrary, Bangladeshi retail SMEs put greater emphasis on their performance in comparison to competitors, as well as non-financial performance in achieving business success. Building on this, the respondents from the two countries have shown that only two of the four aspects of business performance are more important to them. This may be a contributing factor to their business's poor results, as all four components should be given appropriate weight in order to achieve business success. For instance, focusing solely on company development and financial results implies that business owners are unconcerned about the non-financial performance of their business such as customer and employee satisfaction. This could lead to customer dissatisfaction and employee turnover. Consequently, business competitiveness suffers, as owners ignore their company's success in comparison to competitors, implying that owners might not be following the industry's best practices. This could pose a serious threat to the sustainability of such companies compared to their competitors of the same industry. As a result, it is important for Malaysian retail SMEs to boost both their non-financial and financial performances. Similarly, this study has discovered that non-financial success and performance relative to rivals are more important to business owners in Bangladeshi retail SMEs than business growth and financial performance. They believe that putting less emphasis on business development causes their companies to stay small and locally run. As a result, such companies are unable to benefit from the economies of scale that come with expanding their operations.

They might not be able to take advantage of other market opportunities such as internationalization and product exports. Similarly, failing to invest in financial results does not guarantee company sustainability, market share growth, return on investment or cash flow, all of which are critical for successful operations. Companies that invest less in any of the four main dimensions of business success, namely financial performance, non-financial performance, business development and performance relative to competitors, will not be able to achieve long-term competitive advantage and superior performance in the industry. Therefore, in order to achieve successful business performance in any market, these four dimensions must be considered equally.

\subsection{Implications of the study}

The study's practical implications include giving empirical evidence that retail industry entrepreneurs or business owners in Malaysian and Bangladeshi SMEs view the dimensions of their business performance differently. For example, Malaysian retail SME owners

Note(s): Critical $t$-value $2.57^{* * * *}$ (significance level $=1 \%$ )

Source(s): Own survey results

\begin{tabular}{|c|c|c|c|c|c|c|c|}
\hline \multirow[b]{2}{*}{ Relationships } & \multicolumn{3}{|c|}{$\begin{array}{l}\text { Full sample }(N=160) \\
\text { Estimation of } t \text {-values }\end{array}$} & \multicolumn{3}{|c|}{$\begin{array}{l}\text { Full sample }(N=160) \\
\text { Estimation of beta values }\end{array}$} & \\
\hline & $\begin{array}{c}\text { CLC } \\
\text { estimation }\end{array}$ & $\begin{array}{c}\text { ILC } \\
\text { estimation }\end{array}$ & $\begin{array}{l}\text { Original PLS } \\
\text { estimates }\end{array}$ & $\begin{array}{l}\text { CLC } \\
\text { estimation }\end{array}$ & $\begin{array}{c}\text { ILC } \\
\text { estimation }\end{array}$ & $\begin{array}{l}\text { Original PLS } \\
\text { estimates }\end{array}$ & \\
\hline $\mathrm{BS} \rightarrow \mathrm{BG}$ & $25.994^{* * * *}$ & $30.036^{* * *}$ & $31.399^{* * * *}$ & 0.797 & 0.804 & 0.812 & \\
\hline $\mathrm{BS} \rightarrow \mathrm{CP}$ & $27.355^{* * *}$ & $32.192^{* * * *}$ & $30.957^{* * *}$ & 0.839 & 0.844 & 0.849 & \\
\hline $\mathrm{BS} \rightarrow \mathrm{FP}$ & $26.523^{* * * *}$ & $32.523^{* * * *}$ & $30.086^{* * *}$ & 0.815 & 0.815 & 0.820 & Table 13. \\
\hline $\mathrm{BS} \rightarrow \mathrm{NFP}$ & $18.318^{* * * *}$ & $20.351^{* * * *}$ & $21.313^{* * *}$ & 0.754 & 0.768 & 0.769 & coefficients and $t$ - \\
\hline \multicolumn{7}{|c|}{$\begin{array}{l}\text { Note(s): Critical } t \text {-value } 2.57^{* * * *} \text { (significance level }=1 \% \text { ) } \\
\text { Source(s): Own survey results }\end{array}$} & $\begin{array}{l}\text { values in CLC model } \\
\text { and original PLS model }\end{array}$ \\
\hline
\end{tabular}

Dimensions of perceived business success 
RAMJ

17,2

118

consider business growth and financial results to be the most important aspects of their success. Retailers consider financial performance to be more critical than non-financial performance when it comes to the success of their business. Owners of Bangladeshi retail SMEs, on the other hand, see efficiency relative to rivals and non-financial performance as the most important dimensions for achieving business success. In the case of Bangladeshi SMEs, market development and financial results are seen as less significant in achieving business success. Therefore, these results will provide a strong foundation for SME owners (both new and old SMEs) to reconsider business planning in both the short- and long-terms, especially in terms of performance dimensions, as the Malaysian and Bangladeshi business owners from retail SMEs perceive the importance of their business success measures differently.

Malaysian business owners should give equal weight to the other two dimensions, which are performance relative to competitors and non-financial performance, while also considering which is less critical in achieving business success. Likewise, owners of Bangladeshi retail SMEs should prioritize market development and financial results, as they already recognize the value of non-financial performance and performance in comparison to rivals to achieve business success. By fairly emphasizing all four aspects of corporate performance, business owners would be more likely to achieve their goals. This study has provided useful insight to policymakers or decision-makers to consider SME owners' perspectives, which would in turn help them plan training programs for SME owners. Governments in both countries can initiate training programs to educate retail SME owners regarding the importance of all four indicators of business success, which are financial performance, non-financial performance, business growth and performance relative to competitors, because ignoring any one of these four measures could result in failure to sustain their business success in the long run. Therefore, it is utmost important for retail SME owners to be equipped with essential knowledge regarding these four measures of business success so that they can formulate and execute business strategies accordingly to ensure that they can achieve long-term success for their businesses.

The current study's second contribution is to the theory of business success. The dimensions of business success are considered to be significant in particular industries/SMEs in a specific country. In the sense of the same industry/SMEs in other countries, this may not be regarded as equally significant. This study's third methodological contribution is in the using of the most widely recommended CMV detection and control methods, resulting in trustworthy findings. Moreover, the CMV techniques used in this study can be used by future researchers to detect and control potential impacts of CMV or bias while collecting data from the same type of respondents. Richter et al. (2016) acknowledged that second-order models, CMV analysis, HMT criterion, multi-group analysis approaches as well as measurement invariance test are some of the major improvements and methodological advances that are contributing to the popularity of PLS-SEM.

\subsection{Limitations and future recommendations}

The current study's drawback is that it was conducted only in Malaysia and Bangladesh, limiting its applicability to other countries. Hence, this research recommends that a similar study focusing on the ethnicity of business owners be conducted in the future, as it would be beneficial to determine which of the main dimensions of business success are considered to be more critical to achieve business success by business owners of different ethnicities in both countries, or other multi-cultural developing countries. This is because ethnic entrepreneurship and entrepreneurs have long been regarded as critical to an economy's growth (Dana, 2007). Apart from that, additional researches could compare business success measures among family firms and non-family firms, as this study made a contribution from the perception of various contexts. This is due to past literatures' emphasis on the contribution of family businesses to the economy of the country (Ratten et al., 2017; Dana and 
Ramadani, 2015; Ribeiro et al., 2012; Heck et al., 2008). Therefore, it is anticipated that family business owners will view business success in a different light compared to non-family business owners.

\section{References}

Adams, B. and Sykes, V. (2003), "Performance measures and profitability factors of successful African-American entrepreneurs: an exploratory study", Journal of American Academy of Business, Vol. 2 No. 2, pp. 418-424.

Ahmad, N.H. and Seet, P.S. (2009), "Dissecting behaviours associated with business failure: a qualitative study of SME owners in Malaysia and Australia”, Asian Social Science, Vol. 5 No. 9, p. 98.

Ahmad, N.H., Ramayah, T., Wilson, C. and Kummerowidth, L. (2010), "Is entrepreneurial competency and business success relationship contingent upon business environment? A study of Malaysian SMEs", International Journal of Entrepreneurial Behaviour and Research, Vol. 16 No. 3, pp. 182-203.

Ahmad, N.H., Wilson, C. and Kummerow, L. (2011), "Assessing the dimensionality of business success: the perspectives of Malaysian SME owner-managers”, Journal of Asia-Pacific Business, Vol. 12 No. 3, pp. 207-224.

Ahmad, S.Z., Ahmad, N. and Bakar, A.R.A. (2018), "Reflections of entrepreneurs of small and mediumsized enterprises concerning the adoption of social media and its impact on performance outcomes: evidence from the UAE", Telematics and Informatics, Vol. 35, pp. 6-17.

Ahmad, N.H. (2007), "A cross cultural study of entrepreneurial competencies and entrepreneurial success in SMEs in Australia and Malaysia", unpublished doctoral thesis, University of Adelaide.

Amini, A. (2004), "The distributional role of small business in development", International Journal of Social Economics, Vol. 31 No. 4, pp. 370-383.

Arzubiaga, U., Iturralde, T., Maseda, A. and Kotlar, J. (2018), "Entrepreneurial orientation and firm performance in family SMEs: the moderating effects of family, women, and strategic involvement in the board of directors", International Entrepreneurship and Management Journal, Vol. 14 No. 1, pp. 217-244.

Bagozzi, R.P., Yi, Y. and Phillips, L.W. (1991), "Assessing construct validity in organizational research”, Administrative Science Quarterly, pp. 421-458.

Bahar, A.M., Islam, M.A., Hamzah, A., Islam, S.N. and Reaz, M.D. (2020), "The efficacy of work-life balance for young employee retention: a validated retention model for small private industries", International Journal of Process Management and Benchmarking, Vol. 12 No. 2, pp. 1-16.

Beaver, G. (2002), Small Business, Entrepreneurship and Enterprise Development, Pearson Education.

Brüderl, J. and Preisendörfer, P. (1998), "Network support and the success of newly founded business", Small Business Economics, Vol. 10 No. 3, pp. 213-225.

Campbell, D.T. and Fiske, D.W. (1959), "Convergent and discriminant validation by the multitraitmultimethod matrix", Psychological Bulletin, Vol. 56 No. 2, p. 81.

Carton, R.B. and Hofer, C.W. (2006), Measuring Organizational Performance: Metrics for Entrepreneurship and Strategic Management Research, Edward Elgar Publishing.

Chandler, G.N. and Hanks, S.H. (1993), "Measuring the performance of emerging businesses: a validation study", Journal of Business Venturing, Vol. 8 No. 5, pp. 391-408.

Chin, W.W., Thatcher, J.B., Wright, R.T. and Steel, D. (2013), Controlling for Common Method Variance in PLS Analysis: The Measured Latent Marker Variable Approach New Perspectives in Partial Least Squares and Related Methods, Springer, pp. 231-239.

Chin, W.W. (1998), "The partial least squares approach to structural equation modeling", Modern Methods for Business Research, Vol. 295 No. 2, pp. 295-336.
Dimensions of perceived business

success 
RAMJ

17,2

Chin, W.W. (2010), "How to write up and report PLS analyses", in Handbook of Partial Least Squares, Springer, Berlin Heidelberg, pp. 655-690.

Chua, J.H., Chrisman, J.J., De Massis, A. and Wang, H. (2018), "Reflections on family firm goals and the assessment of performance", Journal of Family Business Strategy, Vol. 9 No. 2, pp. 107-113.

Chuang, T.T., Nakatani, K. and Zhou, D. (2009), "An exploratory study of the extent of information technology adoption in SMEs: an application of upper echelon theory", Journal of Enterprise Information Management, Vol. 22 Nos 1/2, pp. 183-196.

Cravo, T.A., Gourlay, A. and Becker, B. (2012), "SMEs and regional economic growth in Brazil", Small Business Economics, Vol. 38 No. 2, pp. 217-230.

Dana, L.P. and Dana, T.E. (2005), "Expanding the scope of methodologies used in entrepreneurship research", International Journal of Entrepreneurship and Small Business, Vol. 2 No. 1, pp. 79-88.

Dana, L.P. and Mallet, J. (2014), "An unusual empirical pattern in an indigenous setting: cooperative entrepreneurship among Brazil nut (Bertholletiaexcelsa) harvesters", International Journal of Entrepreneurship and Small Business, Vol. 22 No. 2, pp. 137-158.

Dana, L.P. and Ramadani, V. (2015), Family Businesses in Transition Economies, Springer International Publishing, Switzerland.

Dana, L.P. (2007), Handbook of Research on Ethnic Minority Entrepreneurship: A Co-Evolutionary View on Resource Management, Edward Elgar Publishing.

Doty, D.H. and Glick, W.H. (1998), "Common methods bias: does common methods variance really bias results?”, Organizational Research Methods, Vol. 1 No. 4, pp. 374-406.

Dutta, D. (2017), "Qualitative approach towards risk assessment and management-an innovative management tool for sustainable development of micro, small and medium enterprises in India”, International Journal of Sustainable Strategic Management, Vol. 5 No. 3, pp. 201-213.

Fornell, C. and Larcker, D.F. (1981), "Evaluating structural equation models with unobservable variables and measurement error", Journal of Marketing Research, pp. 39-50.

Frese, M., Brantjes, A. and Hoorn, R. (2002), "Psychological success factors of small-scale businesses in Namibia: the roles of strategy process, entrepreneurial orientation and the environment", Journal of Developmental Entrepreneurship, Vol. 7 No. 3, p. 259.

Gërguri-Rashiti, S., Ramadani, V., Abazi-Alili, H., Dana, L.P. and Ratten, V. (2017), "ICT, innovation and firm performance: the transition economies context", Thunderbird International Business Review, Vol. 59 No. 1, pp. 93-102.

Gholami, R., Sulaiman, A.B., Ramayah, T. and Molla, A. (2013), "Senior managers' perception on green information systems (IS) adoption and environmental performance: results from a field survey", Information and Management, Vol. 50 No. 3, pp. 431-438.

Götz, O., Liehr-Gobbers, K. and Krafft, M. (2010), "Evaluation of structural equation models using the partial least squares (PLS) approach”, in Handbook of Partial Least Squares, Springer, Berlin Heidelberg, pp. 691-711.

Gupta, N. and Mirchandani, A. (2018), "Investigating entrepreneurial success factors of women-owned SMEs in UAE", Management Decision, Vol. 56 No. 1, pp. 219-232.

Haber, S. and Reichel, A. (2005), "Identifying performance measures of small ventures-the case of the tourism industry", Journal of Small Business Management, Vol. 43 No. 3, p. 257.

Hair, J.F., Black, W.C., Babin, B.J. and Anderson, R.E. (2009), Multivariate Data Analysis, Pearson Prentice Hall, Upper Saddle, NJ.

Hair, J.F., Ringle, C.M. and Sarstedt, M. (2011), "PLS-SEM: indeed, a silver bullet", Journal of Marketing Theory and Practice, Vol. 19 No. 2, pp. 139-152.

Hair, J.F. Jr, Hult, G.T.M., Ringle, C. and Sarstedt, M. (2014), A Primer on Partial Least Squares Structural Equation Modeling (PLS-SEM), Sage Publications. 
Hair, J.F. Jr, Hult, G.T.M., Ringle, C. and Sarstedt, M. (2017), A Primer on Partial Least Squares Structural Equation Modeling (PLS-SEM), Sage Publications.

Hall, G. and Fulshaw, S. (1993), "Factors associated with the relative performance amongst small firms in the British Instrumentation Sector", in Klnadt, H. (Ed.), Entrepreneurship and Business Development, Avebury, Aldershot, pp. 227-237.

Hambrick, D.C. (2007), "Upper echelons theory: an update", Academy of Management Review, Vol. 32 No. 2, pp. 334-343.

Heck, R.K., Hoy, F., Poutziouris, P.Z. and Steier, L.P. (2008), "Emerging paths of family entrepreneurship research", Journal of Small Business Management, Vol. 46 No. 3, pp. 317-330.

Henseler, J., Ringle, C. and Sinkovics, R. (2009), "The use of partial least squares path modeling in international marketing", AdvIntMarket (AIM), Vol. 20 No. 3, pp. 277-320.

Henseler, J., Ringle, C.M. and Sarstedt, M. (2015), "A new criterion for assessing discriminant validity in variance-based structural equation modeling", Journal of the Academy of Marketing Science, Vol. 43 No. 1, pp. 115-135.

Honig, B. and Hopp, C. (2019), "Learning orientations and learning dynamics: understanding heterogeneous approaches and comparative success in nascent entrepreneurship", Journal of Business Research, Vol. 94, pp. 28-41.

Hoong, C.W., Qureshi, Z.H., Sajilan, S. and Al Halbusi, H. (2019), "A study on the factors influencing social entrepreneurial intention among undergraduates", paper presented at 13th International Conference on Mathematics, Actuarial Science, Computer Science and Statistics (MACS), IEEE, pp. 1-7.

Hoque, Z. (2004), "A contingency model of the association between strategy, environmental uncertainty and performance measurement: impact on organizational performance", International Business Review, Vol. 13 No. 4, pp. 485-502.

Hossain, M.S., Islam, M.A. and Haque, A.A. (2021), "Empirical analysis to the factors impact on succession process of the family-owned businesses in Bangladesh, moderating role of education”, doi: 10.1504/IJBIR.2020.10032875.

Islam, M.A., Jantan, A.H., Hunt, A., Rahman, M.F. and Abdullah, M.M. (2019), "Exploration of barriers faced by female graduate entrepreneurs in Bangladesh", Entrepreneurship and Sustainability Issues, Vol. 7 No. 2, pp. 1000-1014.

Islam, M.A., Jantan, A.H., Yusoff, Y.M., Chong, C.W. and Hossain, M.S. (2020), “Green Human Resource Management (GHRM) practices and millennial employees' turnover intentions in tourism industry in Malaysia: moderating role of work environment", Global Business Review, 0972150920907000.

Jakobsen, M. and Jensen, R. (2015), "Common method bias in public management studies", International Public Management Journal, Vol. 18 No. 1, pp. 3-30.

Jennings, P. and Beaver, G. (1997), "The performance and competitive advantage of small firms: a management perspective”, International Small Business Journal, Vol. 15 No. 2, pp. 63-75.

Johara, F., Yahya, S. and Tehseen, S. (2017), "Determinants of future entrepreneurship and entrepreneurial intention", Global Business and Management Research: An International Journal, Vol. 9 No. 4, pp. 80-95.

Karides, M. (2005), "Whose solution is it? Development ideology and the work of micro-entrepreneurs in Caribbean context”, International Journal of Sociology and Social Policy, Vol. 25 Nos 1/2, pp. 30-62.

Kashif, M., Zarkada, A. and Ramayah, T. (2016), "The impact of attitude, subjective norms, and perceived behavioural control on managers' intentions to behave ethically", Total Quality Management and Business Excellence, pp. 1-21.

Khalique, M., Isa, A.H.B.M., Shaari, N., Abdul, J. and Ageel, A. (2011), "Challenges faced by the small and medium enterprises (SMEs) in Malaysia: an intellectual capital perspective", International Journal of Current Research, Vol. 3 No. 6, pp. 398-401.

Dimensions of perceived business

success 
RAMJ

17,2

Liao, S., Liu, Z. and Zhang, S. (2018), "Technology innovation ambidexterity, business model ambidexterity, and firm performance in Chinese high-tech firms", Asian Journal of Technology Innovation, Vol. 26 No. 3, pp. 325-345.

Lindell, M.K. and Whitney, D.J. (2001), "Accounting for common method variance in cross-sectional research designs”, Journal of Applied Psychology, Vol. 86 No. 1, pp. 114-121.

Marlow, S. and Strane, A. (1994), "Female entrepreneurs: success by whose standards", in Women in Management: A Developing Presence, pp. 72-184.

Mekraz, A. and Gundala, R.R. (2016), "Leadership style and retail store performance-a case study of discount retail chain”, Journal of Business and Retail Management Research, Vol. 10 No. 2, pp. 1-10.

Ministry of Industries (2016), available at: http://moind.portal.gov.bd/sites/default/files/files/ moind.portal.gov.bd/policies/55dad52c_913d_487d_b59a_26db59742b4920 (accessed 15 September 2016).

Nik, N.A.H., Yaakub, S. and Subhan, M. (2016), "Logistics and supply chain related issues faced by Malaysian SMEs: a case study", International Review of Management and Marketing, Vol. 6 No. 3, pp. 432-435.

North, K. and Varvakis, G. (2016), Competitive Strategies for Small and Medium Enterprises: Increasing Crisis Resilience, Agility and Innovation in Turbulent Times, Springer.

O'Regan, N. and Ghobadian, A. (2004), "The importance of capabilities for strategic direction and performance", Management Decision, Vol. 42 No. 2, pp. 292-313.

Perren, L. (2000), "Factors in the growth of micro-enterprises (part 2): 'Exploring the implications", Journal of Small Business and Enterprise Development, Vol. 7 No. 1, pp. 58-68.

Podsakoff, P.M., MacKenzie, S.B., Lee, J.Y. and Podsakoff, N.P. (2003), "Common method biases in behavioral research: a critical review of the literature and recommended remedies", Journal of Applied Psychology, Vol. 88 No. 5, p. 879.

Radam, A., Abu, M.L. and Abdullah, A.M. (2008), "Technical efficiency of small and medium enterprise in Malaysia: a stochastic Frontier production model", International Journal of Economics and Management, Vol. 2 No. 2, pp. 395-408.

Rahman, S.A., Taghizadeh, S.K., Ramayah, T. and Ahmad, N.H. (2015), "Service innovation management practices in the telecommunications industry: what does cross country analysis reveal?", Springer Plus, Vol. 4 No. 1, p. 810.

Rai, A., Patnayakuni, R. and Seth, N.D. (2006), "Firm performance impacts of digitally enabled supply chain integration capabilities", MIS Quarterly, Vol. 30 No. 2, pp. 225-246.

Rakićević, Z., Omerbegović-Bijelović, J. and Lečić-Cvetković, D. (2016), "A model for effective planning of SME support services", Evaluation and Program Planning, Vol. 54 No. 1, pp. 30-40.

Ramadani, V., Rexhepi, G., Gërguri-Rashiti, S., Ibraimi, S. and Dana, L.P. (2014), "Ethnic entrepreneurship in Macedonia: the case of Albanian entrepreneurs", International Journal of Entrepreneurship and Small Business, Vol. 23 No. 3, pp. 313-335.

Ratten, V., Dana, L.P. and Ramadani, V. (2017), "Internationalisation of family business groups in transition economies", International Journal of Entrepreneurship and Small Business, Vol. 30 No. 4, pp. 509-525.

Rezaei, S., Goli, M. and Dana, L.P. (2013), "Informal opportunity among SMEs: an empirical study of Denmark's underground economy", International Journal of Entrepreneurship and Small Business, Vol. 19 No. 1, pp. 64-76.

Ribeiro, A., Rezaei, S. and Dana, L.P. (2012), "Gender and family in transnational entrepreneurship", International Journal of Business and Globalization, Vol. 8 No. 3, pp. 409-420.

Richardson, H.A., Simmering, M.J. and Sturman, M.C. (2009), "A tale of three perspectives: examining post hoc statistical techniques for detection and correction of common method variance", Organizational Research Methods, Vol. 12 No. 4, pp. 762-800. 
Richter, N.F., Sinkovics, R.R., Ringle, C.M. and Schlägel, C. (2016), "A critical look at the use of SEM in international business research”, International Marketing Review, Vol. 33 No. 3, pp. 376-404.

Sajilan, S. and Tehseen, S. (2015), "Cultural orientations, entrepreneurial competencies and SMEs business success: the contingent roles of environmental turbulence and network competence", Review of Integrative Business and Economics Research, Vol. 4 No. 2, p. 20.

Schauer, D. and Hoy, F. (2001), "The continuing search for relevance in small business and entrepreneurship research", Academy of Entrepreneurship Journal, Vol. 7 No. 1, p. 11.

Shanine, K.K., Eddleston, K.A. and Combs, J.G. (2019), "Same boundary management preference, different outcome: toward a gendered perspective of boundary theory among entrepreneurs", Journal of Small Business Management, Vol. 57 No. 1, pp. 185-205.

SME Corp (2015), "Sme corp gov my", available at: https://www.smecorp.gov.my (accessed 14 June 2017).

Śmigielska, G. (2016), "The role of an entrepreneur in developing an organizational culture fostering innovations", Studia Oeconomica Posnaniensia, Vol. 4 No. 5, pp. 54-68.

Stephan, U. (2018), "Entrepreneurs' mental health and well-being: a review and research agenda", Academy of Management Perspectives, Vol. 32 No. 3, pp. 290-322.

Tehseen, S. and Ramayah, T. (2015), "Entrepreneurial competencies and SMEs business success: the contingent role of external integration”, Mediterranean Journal of Social Sciences, Vol. 6 No. 1, p. 50.

Tehseen, S. and Sajilan, S. (2016), "Impact of innovative practices on business growth under the moderating impacts of culture-a conceptual model", Review of Integrative Business and Economics Research, Vol. 5 No. 2, pp. 28-46.

Tehseen, S., Sajilan, S., Ramayah, T. and Gadar, K. (2015), "An intra-cultural study of entrepreneurial competencies and SMEs business success in wholesale and retail industries of Malaysia: -a conceptual model", Review of Integrative Business and Economics Research, Vol. 4 No. 3, pp. 33-48.

Tehseen, S., Ramayah, T. and Sajilan, S. (2017), "Testing and controlling for common method variance: a review of available methods", Journal of Management Sciences, Vol. 4 No. 2, pp. 142-168.

Tehseen, S., Qureshi, Z.H., Johara, F. and Ramayah, T. (2019), "Assessing perceived business success as a reflective-formative (Type II) second-order construct using PLS-SEM approach", Journal of Sustainability Science and Management, Vol. 14 No. 5, pp. 84-114.

Tehseen, S., Qureshi, Z.H., Johara, F. and Ramayah, T. (2020a), "Assessing dimensions of entrepreneurial competencies: a type II (reflective-formative) measurement approach using PLS-SEM", Journal of Sustainability Science and Management, Vol. 15 No. 2, pp. 108-145.

Tehseen, S., Khalid, S., Rather, R.A., Qureshi, Z.H. and Halbusi, H.A. (2020b), "HRM practices for knowledge management and retail firms' performances: a comparative study among Malay and Chinese firms", International Journal of Entrepreneurship, Vol. 24 No. 1, pp. 1-7.

Tennant, V.M. (2014), "Understanding changes in post-adoption use of information systems (IS): a generalized Darwinism perspective”, Doctoral Dissertation, University of Canterbury.

Velte, P. (2017), "Do women on board of directors have an impact on corporate governance quality and firm performance? A literature review", International Journal of Sustainable Strategic Management, Vol. 5 No. 4, pp. 302-346.

Walker, E. and Brown, A. (2004), "What success factors are important to small business owners?", International Small Business Journal, Vol. 22 No. 6, pp. 577-594.

Welter, F. and Gartner, W.B. (Eds) (2016), A Research Agenda for Entrepreneurship and Context, Edward Elgar Publishing.

Whitson, J.R., Simon, B. and Parker, F. (2018), "The missing producer: rethinking indie cultural production in terms of entrepreneurship, relational labour, and sustainability", European Journal of Cultural Studies, 1367549418810082.
Dimensions of perceived business success 
RAMJ

17,2

Williams, L.J., Hartman, N. and Cavazotte, F. (2010), "Method variance and marker variables: a review and comprehensive CFA marker technique", Organizational Research Methods, Vol. 13 No. 3, pp. 477-514.

Yan, S. (2015), "A theoretical framework of competitive advantage for SMEs in China under new normal economy", European Scientific Journal, Vol. 11 No. 34, pp. 1-12.

Yuksel, A. (2017), “A critique of 'response bias' in the tourism, travel and hospitality research", Tourism Management, Vol. 59 No. 3, pp. 376-384.

Yung, Y.F. and Bentler, P.M. (1994), "Bootstrap-corrected ADF test statistics in covariance structure analysis", British Journal of Mathematical and Statistical Psychology, Vol. 47 No. 1, pp. 63-84.

Zahan, M. (2017), "The economic sustainability of small business: an empirical analysis on the mobile phone banking in Dhaka City", International Journal of Sustainable Strategic Management, Vol. 5 No. 3, pp. 231-244.

Zakariaa, N., Abdullaha, N.A.C. and Yusoffa, R.Z. (2016), "The innovation-performance linkage: empirical evidence of Malaysian manufacturing SMEs", paper presented at International Soft Science Conference (ISSC).

\section{Further reading}

Ahmed, Z., Gull, M. and Rafiq, U. (2015), "Factors affecting consumer switching behavior: mobile phone market in Manchester-United Kingdom", International Journal of Scientific and Research Publications, Vol. 5 No. 7, pp. 1-7.

Anderson, E.W. and Fornell, C. (2000), "Foundations of the American customer satisfaction index", Total Quality Management, Vol. 1 No. 7, pp. 869-882.

Bin, H. and Lazim, D.S. (2015), "What factor persuade Malaysians consumer to purchase smartphone? ", Journal of Technology and Operations Management, Vol. 10 No. 2, pp. 38-50.

Byrne, B.M. (1994), Structural Equation Modeling with EQS and EQS/Windows, Sage Publications, Thousand Oaks, CA.

Chen, Y.S., Chen, T.J. and Lin, C.C. (2016), "The analyses of purchasing decisions and brand loyalty for Smartphone consumers", Open Journal of Social Sciences, Vol. 4 No. 7, pp. 108-116.

Hashim, J. (2008), "Competencies acquisition through self-directed learning among Malaysian managers", Journal of Workplace Learning, Vol. 20 No. 4, pp. 259-271.

Matook, S. (2013), "Measuring the performance of electronic marketplaces: an external goal approach study", Decision Support Systems, Vol. 54 No. 2, pp. 1065-1075.

\section{Corresponding author}

Md Asadul Islam can be contacted at: mislam@swinburne.edu.my

For instructions on how to order reprints of this article, please visit our website:

www.emeraldgrouppublishing.com/licensing/reprints.htm

Or contact us for further details: permissions@emeraldinsight.com 